\title{
Circumventing the 'That-Trace' Effect: Different Strategies between Germanic and Romance
}

\author{
Andrea Padovan ${ }^{1, *(\mathbb{D}}$, Ermenegildo Bidese ${ }^{2}$ and Alessandra Tomaselli ${ }^{1}$ \\ 1 Dipartimento di Lingue e Letterature Straniere, Università di Verona, 37129 Verona, Italy; \\ alessandra.tomaselli@univr.it \\ 2 Dipartimento di Lettere e Filosofia, Università di Trento, 38122 Trento, Italy; ermenegildo.bidese@unitn.it \\ * Correspondence: andrea.padovan@univr.it
}

\section{check for}

updates

Citation: Padovan, Andrea,

Ermenegildo Bidese, and Alessandra

Tomaselli. 2021. Circumventing the

'That-Trace' Effect: Different

Strategies between Germanic and

Romance. Languages 6: 84. https://

doi.org/10.3390/languages6020084

Academic Editors: Ángel Gallego,

Bruno Camus, Ricardo Etxepare,

Iván Ortega-Santos, Diego Pescarini,

Francesc Roca, Juan Uriagereka and

Greta Mazzaggio

Received: 15 March 2021

Accepted: 19 April 2021

Published: 11 May 2021

Publisher's Note: MDPI stays neutral with regard to jurisdictional claims in published maps and institutional affiliations.

Copyright: (C) 2021 by the authors. Licensee MDPI, Basel, Switzerland. This article is an open access article distributed under the terms and conditions of the Creative Commons Attribution (CC BY) license (https:/ / creativecommons.org/licenses/by/ $4.0 /)$.

\begin{abstract}
In our paper, we deal with the Germanic-Romance language contact, focusing on Cimbrian, a Germanic minority language spoken in Northern Italy. Specifically, we focus on the violation of the well-known that-trace filter, as it appears to be an interesting case of the superficial convergence that we ascribe to the status of $\mathrm{T}$, which is either too rich (model language) or too weak (replica language) to represent a viable landing site for subject extraction.
\end{abstract}

Keywords: minority languages; that-trace violation; null subject parameter; Cimbrian; Bavarian; complementizer agreement

\section{Introduction}

Cimbrian ${ }^{1}$ is a German(ic) minority language which has long been in contact with Romance varieties in Northeast Italy. It belongs to the group of Southern Bavarian-Austrian dialects from which it has been isolated since the 11th Century (see Bidese 2004); however, it has preserved some morpho(phono)logical features that are common with its medieval cognates (see, among others, Bidese 2010). The three varieties of Cimbrian currently spoken are: (i) the Luserna variety (Province of Trentino-Alto Adige/Südtirol); (ii) the one in the so-called area of the Tredici Comuni (lit. "Thirteen Municipalities") in the Province of Verona (Veneto Region) - where Cimbrian is essentially alive in the village of Giazza/Ljetzan only); (iii) the one in the so-called area of the Sette Comuni (lit. "Seven Municipalities"), close to Asiago, in the Province of Vicenza (Veneto Region) - where only a few Cimbrian speakers are found in the village of Roana/Robaan. The data discussed in this work have been collected in Luserna, i.e., the only variety actively spoken in a community of ca. 300 inhabitants.

The most remarkable aspect in the syntax of Cimbrian at the sentence level is that it has lost the core property of the verb second (V2) phenomenon, i.e., the well-known linear restriction, found in the Continental West-Germanic and Scandinavian languages (see Bidese 2008). However, it has retained facets of its Germanic origin in maintaining the mandatory V-to-C (/FinP, assuming a cartographic perspective on the C-layer) movement in root clauses with residual effects on both subject inversion and the root-embedded word order asymmetry (limited to a specific class of lexical complementizers) (for more details, see Bidese et al. 2020).

Moreover, Cimbrian resembles other "well-behaved" Germanic languages, as it is a non-pro-drop language (cf. 1a, below) (see Bidese 2008; Bidese and Tomaselli 2018), different from all the Romance varieties with which it has been in contact for centuries. In fact, Cimbrian has maintained a lexical expletive with both weather verbs and as a correlate of a postponed subject clause.

1 The most part of the data discussed are taken from previous literature; novel data concerning the that- $t$ effect have been collected both with dedicated fieldwork and from the crowdsourcing platform, www.vinko.it (accessed on 15 March 2021). We express our deep gratitude to our excellent informant ANG. 
In this paper, we deal with the unexpected fact that Cimbrian, in fact, aligns with Romance, when it comes to the that-t effect. Pro-drop languages, such as Italian, are known to bleed the that-t effect due to free subject inversion: this property has been assumed to be a corollary of the null subject parameter since Rizzi (1982). We will show that Cimbrian displays a special kind of subject inversion, which combines properties that typologically belong to both German and Italian, circumventing the that-t effect in an original way, with an interesting overlapping with complementizer agreement in Bavarian. We argue that what all these varieties have in common is a "weakened" status of [Spec, TP]—even if this is due to the opposite value of the null subject parameter in each language.

\section{The Nuts and Bolts of Cimbrian Syntax}

\subsection{V2 and Subject Inversion in Cimbrian}

Cimbrian is taken to be a so-called "relaxed" V2 language (see Bidese et al. 2012a, 2012b), i.e., a language with obligatory V-to-C movement, not displaying the expected linear restriction that is usually found in the Germanic languages, with the well-known exception of Modern English: this means that more than one constituent can occur in front of the finite verb, and the subject shows up among them in Cimbrian. In fact, independent of how many phrases are fronted, the unmarked positions for DP subjects and full pronouns always correspond to the preverbal one, cf. the italicized phrases in $(1 a, b)$ :
1. a. [Allz in an stroach] [in balt] [dar pua] hatt gesek in vuks 'All of a sudden, the boy saw the fox in the wood.' all of a sudden in.the wood the.NOM boy has seen the.ACC fox
b. [Allz in an stroach] [in balt $] \quad$ [er $] \quad$ hatt gesek in vuks all of a sudden in.the wood he.NOM has seen the.ACC fox 'All of a sudden, he saw the fox in the wood.'

With respect to this typology of subjects, the typical German-like inversion (=VfinDPsubj) is excluded, as (3) shows:
2. *[Allz in an stroach] all of a sudden
[in balt] in.the wood
hatt
dar pua
gesek
in vuks
has
the.NOM boy
seen
the.ACC fox

Even if the finite verb does not show up as a second constituent (cf. 1 and 2), there is strong evidence to assume that it moves into the left periphery of the sentence, i.e., C, as it is generally taken for Germanic varieties starting from den Besten (1983): in fact, Cimbrian clitic subject pronouns are realized on the right of the finite verb, in the so-called Wackernagel position, and encliticized onto the finite verb (Vfin=CL) (cf. 3) (see Tomaselli and Bidese 2019):
3. a. [Allz in an stroach] [in balt] hatt=ar gesek in vuks all of a sudden in.the wood has=he.CL seen the.ACC fox
'All of a sudden, he saw the fox in the wood.'
b. * [Allz in an stroach]
$\begin{array}{ll}\text { [in balt] } & \text { [ar] } \\ \text { in.the wood } & \text { he.CL }\end{array}$
hatt gesek
in vuks all of a sudden$$
\text { has seen }
$$
the fox

$$
\text { in.the wood he.CL }
$$

Nevertheless, Cimbrian displays a special kind of nominal subject inversion with the whole verbal complex: the examples in (4) and (5) feature a special element, i.e., the segment $-t a$, an allomorph of the enclitic particle $-d a$, which plays a crucial role in our story and will be focused on in the next section: 
4. Haüt iz-*(ta) khent dar nono

today is-da.CL arrived the.NOM grandpa

'Grandpa arrived today.'

5. a. [Allz in an stroach] [in balt] hatt- ${ }^{*}(a)^{2}$ gesek DARPUA in has all of a sudden in.the wood has-da.CL seen the boy the.ACC hare

'It was the boy that saw the hare suddenly in the wood.'

\begin{tabular}{|c|c|c|c|c|}
\hline $\begin{array}{l}\text { b. [Allz in an stroach] } \\
\text { yesterday }\end{array}$ & $\begin{array}{l}\text { [in balt] } \\
\text { in the wood }\end{array}$ & $\begin{array}{l}\text { hatt-*(a) } \\
\text { has-da.CL }\end{array}$ & $\begin{array}{l}\text { gesek } \\
\text { seen }\end{array}$ & $\begin{array}{l}\text { in has } \\
\text { the hare }\end{array}$ \\
\hline
\end{tabular}
'It was the boy that saw the hare suddenly in the wood'

In (4) and (5), the subject always shows up postverbally; however, it receives a presentative reading when it occurs with an unaccusative verb; in transitive constructions, it can be interpreted either as a contrastive focus (5a) or as a new information focus (5b) (see Bidese and Tomaselli 2018, for more details).

The inversion with the whole verbal complex (=VP DP) is a well-known phenomenon in Italian (cf. Rizzi 2004 or Belletti 2004, among many others), whereas in the Germanic languages, it is marginal and usually analyzed in a different way: for instance, English postverbal subjects associated with the expletive there (such as There arrived a man) are assumed to be VP-internal, provided that there is a definiteness effect on the subject. On the contrary, postverbal subjects in Italian can even be extraposed, as in Ha comprato il giornale il nonno (for a detailed analysis on the DP subject position in Cimbrian, we refer the reader to Bidese and Tomaselli 2018).

Interestingly, the examples (4) and (5) resemble their Italian counterparts, except for the mandatory presence of the enclitic expletive particle $-d a$; the next subsection is devoted to the morphosyntactic properties of this element of the Cimbrian syntax.

\subsection{The Role of the Enclitic Particle-da}

As we pointed out in Section 2.1, the DP subject can occur in a pre-verbal position (cf. 1a); or, it inverts with the whole VP (cf. 4) cooccurring with the enclitic expletive $-d a$. Generally, this holds true in the case of unaccusative verbs $(6 a, b)$; however, it can be generalized to transitive constructions as well. See (7), where (7b) displays a context of contrastive reading.

6

today is-da.CL

'Grandpa arrived today.'

b. Haüt soin- ${ }^{*}(\mathrm{da})$

today are-da.CL arrived

'(My) grandparents arrived today.'

$\begin{array}{ll}\text { khent } & \text { dar nono } \\ \text { arrived } & \text { the grandpa }\end{array}$

di noni

the grandparents
hat-*(ta)
gesek in has
dar pua yesterday in.the forest has-da.CL seen the hare the boy 'It was the boy that saw the hare yesterday in the wood.'
b. Gestarn in balt hat ${ }^{*}$ (ta) gesek dar pua in has (nèt di diarn) yesterday in.the forest has-da.CL seen the boy the hare (not the girl)

\subsection{A Hybrid Subordination System}

As regards the embedded declarative clauses in Cimbrian, both traditional grammars (see Panieri et al. 2006) and formal analyses (see Grewendorf and Poletto 2009; Padovan 2011; Bidese et al. 2012a, 2013; Bidese and Tomaselli 2016) point out that the complementation system is hybrid in the sense that it consists of two different complementizers

2 The 3.pers.sing. form of the auxiliary håm (have), hatta (hatt $+d a$ ), results from the assimilation of the voiceless ending - $t$ with the expletive particle $-d a$. The same holds for the 3.pers.sing. form of the auxiliary soin (be) $i z-t a(i z+d a)$. 
corresponding to the English that: an autochthonous one, $a z$, which hosts the unstressed pronominal forms and the enclitic expletive - $d a$, triggering the embedded word order (see 8 ), and a Romance loanword, ke, which cannot host any enclitic elements and manifests the same word order as in the main clauses (cf. 9).

8. I bill azz=ar nèt gea ka Roma

I want that=he.CL not go.SBJV to Rome

'I want him not to go to Rome.'

9. Iboaz ke er geat nèt ka Roma

I know that he goes not to Rome

'I know he doesn't go to Rome.'

Typically, nonfactive (e.g., volitional verbs such as bölln, 'want') and non-assertive verbs (sperarn, 'hope') and negated forms (bridge verbs such as net gloam, 'think that not $\mathrm{V}^{\prime}$ ) select az: in this case, Vfin undergoes a shorter movement than it does in the main clauses, as it follows Neg and sentential adverbials (see Padovan 2011). Moreover, az hosts morpho-phonologically reduced pronominal forms and the enclitic expletive subject - $d a$ (see Kolmer 2005; Bidese et al. 2012b, 2020; Bidese and Tomaselli 2018).

The second complementizer is ke: clearly, it is a loanword from Italian/Romance. It is selected by assertive verbs (bizzan, 'know'), perception verbs (seng, 'see/observe'), and weak assertive verbs (pensarn, 'think'). Ke has been assumed to be a subordinator rather than a full-fledged clause-typer, as it is in the case of $a z$. In fact, contrary to $a z$, it does not affect the word order. Furthermore, $k e$-introduced clauses typically display root phenomena such as postverbal negation and subject-verb inversion. Finally, ke cannot host either clitics or the expletive $-d a$.

The dichotomy

$$
\begin{aligned}
& \text { non-factive matrix verb-az-Neg Vfin }{ }_{[\text {Mood: SBJV] }} \\
& \text { vs. } \\
& \text { factive/assertive matrix verb-ke-Vfin }[\text { Mood: IND] } \mathrm{Neg}
\end{aligned}
$$

reminds us of the well-known difference between non-assertive and assertive complement clauses in the Scandinavian languages, where exactly the same word order patterns are found (Neg V vs. V Neg); although—in contrast to Cimbrian-the complementizer (at) and mood (indicative) are used in both contexts (see Bidese 2017).

In fact, Norwegian and Swedish clearly show a V $>$ Neg vs. Neg $>$ V asymmetry between assertive and non-assertive complements. While $\mathrm{V}>\mathrm{Neg}$ introduces clauses with V2 structure (cf. 10a and 11a), Neg $>$ V does not (cf. 10b and 11b) (the data are taken from Wiklund et al. 2009):

10 a. Han sa at han kunne ikke synge ibryllupet he said that he could not sing in wedding-the 'He said that he could not sing at the wedding.'

b. *Han tvilte på at hun hadde ikke møtt denne mannen he doubted on that she had not met this man-the 'He doubted that she hadn't met this man.'

11 a. Han sa att han kunde inte sjunga på bröllopet he said that he could not sing on wedding-the 'He said that he could not sing at the wedding.'

$\begin{array}{llllllllll}\text { b. } & * \text { Han } & \text { tvivlar pa } & \text { att } & \text { hon } & \text { har } & \text { inte träffat den } & \text { här } & \text { mannen } \\ \text { he } & \text { doubts } & \text { on } & \text { that } & \text { she } & \text { has } & \text { not } & \text { met } & \text { this } & \text { here }\end{array}$ 'He doubts that she hasn't met this man.'

After presenting the Cimbrian subordination system, it is interesting to note that, in embedded clauses introduced by $a z$, the expletive particle - $d a$ is still mandatory, regardless 
of the position of the DP subject (see 12a and 12b). On the contrary, in embedded clauses introduced by $k e,-d a$ is present only when the DP subject shows up postverbally, exactly as in the case of main clauses (cf. 13a vs. 13b):

\begin{tabular}{|c|c|c|c|c|c|c|c|c|}
\hline 12. a. & $\begin{array}{l}\text { I } \\
\text { I } \\
\{\text { dar nono }\} \\
\text { the grandpa }\end{array}$ & $\begin{array}{l}\text { sperar } \\
\text { hope }\end{array}$ & $\begin{array}{l}\text { az- }^{*}(\mathrm{ta}) \\
\text { that-da.CL } \\
\text { atz Lusern } \\
\text { at Luserna }\end{array}$ & $\begin{array}{l}\{\text { dar nono }\} \\
\text { the grandpa } \\
\{\text { dar nono }\} \\
\text { the grandpa }\end{array}$ & $\begin{array}{l}\text { khemm } \\
\text { arrive.SBJV }\end{array}$ & $\begin{array}{l}\{\text { dar nono }\} \\
\text { the grandpa }\end{array}$ & & $\begin{array}{l}\text { haüt } \\
\text { today }\end{array}$ \\
\hline & \multicolumn{8}{|c|}{ 'I hope that grandpa arrives in Luserna today.' } \\
\hline b. & $\begin{array}{l}\text { I } \\
\text { I }\end{array}$ & $\begin{array}{l}\text { sperar } \\
\text { hope } \\
\text { \{di diarn\} } \\
\text { the girl } \\
\text { 'I hope tha }\end{array}$ & $\begin{array}{l}\text { az- }^{*}(\mathrm{ta}) \\
\text { that-da.CL }\end{array}$ & $\begin{array}{l}\{\text { di diarn }\} \\
\text { the girl }\end{array}$ & $\begin{array}{l}\text { habe } \\
\text { have.sbjv }\end{array}$ & $\begin{array}{l}\text { gesek } \\
\text { seen }\end{array}$ & $\begin{array}{l}\{\text { di diarn }\} \\
\text { the girl }\end{array}$ & $\begin{array}{l}\text { in has } \\
\text { the hare }\end{array}$ \\
\hline 13. a. & $\begin{array}{l}\text { I } \\
\text { I }\end{array}$ & $\begin{array}{l}\text { boaz } \\
\text { know } \\
\text { 'I know gr }\end{array}$ & $\begin{array}{l}\text { ke } \\
\text { that } \\
\text { pa is comin }\end{array}$ & $\begin{array}{l}\text { dar nono } \\
\text { the granpa } \\
\text { userna today.' }\end{array}$ & $\begin{array}{l}\left.\text { khint- }{ }^{*} a\right) \\
\text { comes }\end{array}$ & $\begin{array}{l}\text { haüt } \\
\text { today }\end{array}$ & $\begin{array}{l}\text { atz Lusern } \\
\text { at Luserna }\end{array}$ & \\
\hline b. & $\begin{array}{l}\text { I } \\
\text { I }\end{array}$ & $\begin{array}{l}\text { boaz } \\
\text { know }\end{array}$ & $\begin{array}{l}\text { ke } \\
\text { that }\end{array}$ & $\begin{array}{l}\text { haüt } \\
\text { today }\end{array}$ & $\begin{array}{l}\text { khint- }^{*}(a) \\
\text { comes }\end{array}$ & $\begin{array}{l}\{\text { dar nono }\} \\
\text { the granpa }\end{array}$ & $\begin{array}{l}\text { atz Lusern } \\
\text { at Luserna }\end{array}$ & $\begin{array}{l}\{\text { dar nono }\} \\
\text { the grandpa }\end{array}$ \\
\hline
\end{tabular}

The data in (12) und (13) show that the expletive - $d a$ is obligatory whenever the DP subject does not leave the v-layer in a postverbal position in the main clauses and in the subordinates introduced by $k e$; it also does not leave the v-layer in a preverbal position in instances where $a z$ is the complementizer. For our purposes, it is not substantial to determine whether the DP subject is VP-internal or extraposed. ${ }^{3}$ What is crucial is that the DP is not raised to [Spec, FinP], which is always the case in the embedded clause introduced by $a z$ (see Bidese and Tomaselli 2018).

\section{How Cimbrian Circumvents the That-Trace Effect: Free Subject Inversion}

\subsection{Absence of That-Trace Effect in Cimbrian}

A well-known fact regarding the that-trace effect (henceforth that- $t$ ) is that it correlates with the null subject parameter (see Rizzi 1982 and much subsequent work): a prototypical pro-drop language, e.g., Italian, does not display that- $t$ effects, whereas English-as a prototypical non-pro-drop language-does.

14.
$\begin{array}{ll}\text { a. } & \varnothing \text { Parla } \\ \text { b. } & \varnothing \text { Piove }\end{array}$
*(S/he) speaks
c. $\quad \varnothing$ È chiaro che non verrà
*(it) is raining
*(it) is clear that he
will not come
d. Chi credi che $\varnothing$ verrà $t$ ?
Who do you think
*(that) $t$ will come $t$ ?

3 Nevertheless, an extraposed position for the subject resembling the Italian construction (cf. 12b,13b) appears to be less likely, as "real" extraposed constructions require a personal pronoun endowed with the same phi-features bundle as the extraposed DP, which can also become optional (cf. i.b-ii.b vs. i.a-ii.a):

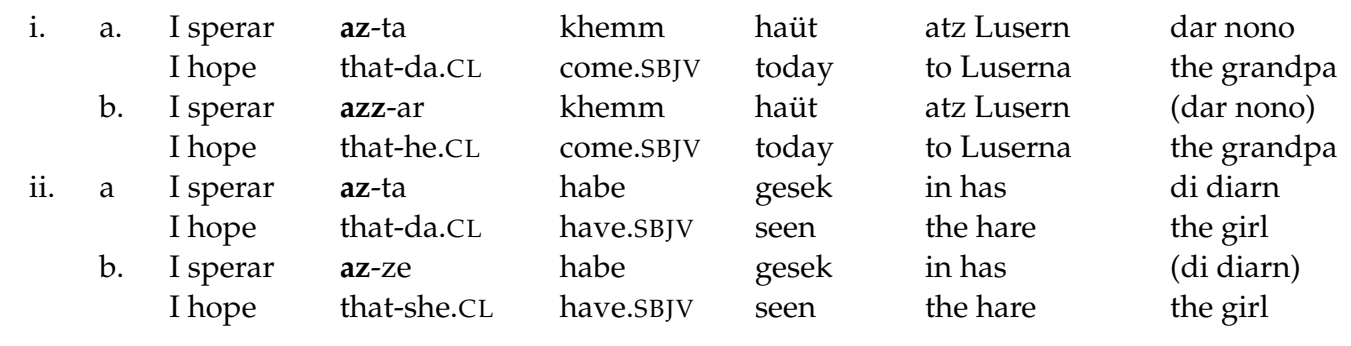


Apropos the focus of our study, the that-t phenomena in Cimbrian, the following are to be considered. First, Cimbrian is a non-pro-drop language, as the following examples show:

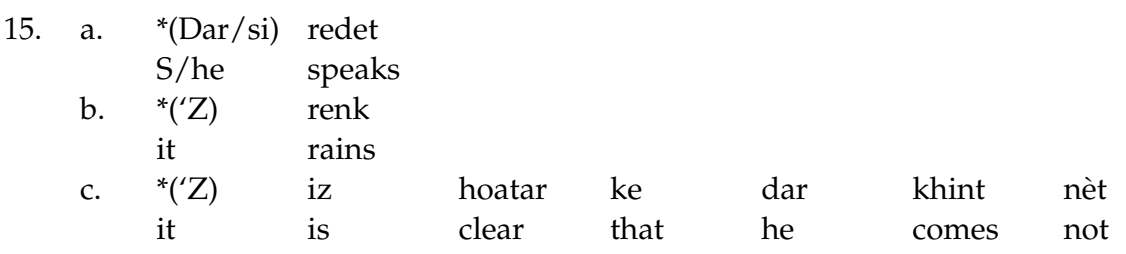

Because of this correlation with the Null Subject Parameter, we expect the presence of the overt complementizer to violate the that- $t$ filter. However, bearing in mind the parallel between Cimbrian and Italian with respect to low (i.e., non-raised) DP subjects (6-7-12-13), we might surmise that Cimbrian allows subject extraction from the postverbal position in the embedded clause, independent of the verbal class (with both unaccusative and transitive verbs). In other words, there should be no that-t effect in the same fashion as in Italian. This is indeed confirmed by our data (cf. 16a) with the complementizer $a z$. Notice, however, that the absence of the that- $t$ effect is not affected by the choice of the complementizer (cf. Section 2.3); i.e., it is independent from whether or not the embedded clause is introduced by az or $k e$ :

\begin{tabular}{|c|c|c|c|c|c|c|}
\hline 6. a. & & $\begin{array}{l}\text { gloabest-(t)o } \\
\text { believe-you.CL }\end{array}$ & $\begin{array}{l}\text { az- } t a \\
\text { that-da.CL }\end{array}$ & ber & $\begin{array}{l}\text { khemm } \\
\text { comes.SB] }\end{array}$ & \\
\hline & \multicolumn{6}{|c|}{ 'Who do you think is coming?' } \\
\hline b. & $\begin{array}{l}\text { Ber } \\
\text { who }\end{array}$ & $\begin{array}{l}\text { khüst-(t)o } \\
\text { say-you.CL }\end{array}$ & $\begin{array}{l}\mathbf{k e} \\
\text { that }\end{array}$ & $\begin{array}{l}\text { 'z } \\
\text { expl }\end{array}$ & $\begin{array}{l}\text { iz-ta } \\
\text { is-da.CL }\end{array}$ & $\begin{array}{l}\text { ber } \\
\text { come }\end{array}$ \\
\hline
\end{tabular}

As already pointed out, it is not relevant from which position ber is extracted: what is important here is that [Spec, TP] is not targeted by successive-cyclic movement.

As a matter of fact, you might recall that Cimbrian does not allow the verb-subject inversion found in German, where the DP-Subject is merged in [Spec, TP], as shown in (2) and repeated here as (17):

17. *[Allz in an stroach] [in balt] hatt $\quad$ TP [SPEC [ all of a sudden in.the wood has the.NOM boy seen the.ACC fox

For the same reason, a wh-extraction through a C-head not hosting the expletive particle $-d a$ is not possible, as this would amount to the subject being in [Spec, TP]:

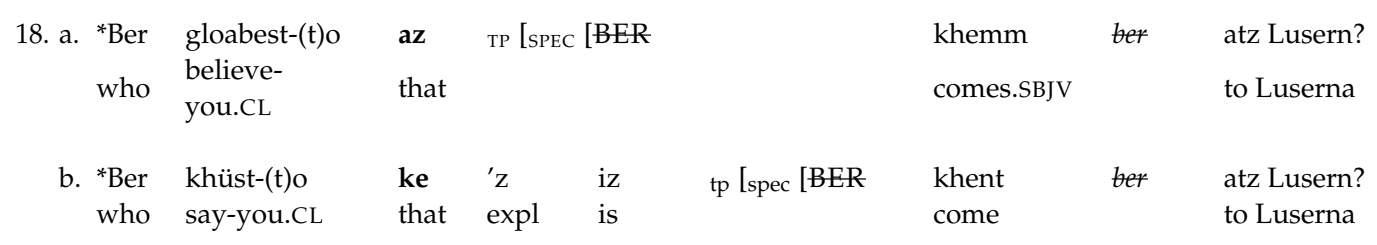

As we have seen in Section 2.3, ke does not trigger the matrix/embedded asymmetry, as is the case with $a z$. This is also confirmed by the presence of the expletive ' $z$ (corresponding to the German Vorfeld es), while the enclitic expletive -da has to be taken as the signal of the lower (/vP internal) position of the extracted subject (see Bidese and Tomaselli 2018).

\subsection{The Proposal}

Pesetsky (2017) distinguishes between linear accounts and structure-based accounts of the that-t effect: the former accounts bar the extraction from a position right-adjacent to COMP; the latter accounts focus on the particular extraction sites and ban movement that are too local. In particular, quoting Pesetsky, "Most of structure-based accounts build on the independent observation that successful A-bar-movement appears to proceed successivecyclically through the edges of domains such as CP. Complementizer-trace effects are 
attributed [ ... ] to some consequences of movement from the subject position to a position in the complementizer system that is affected by the presence, absence of featural content of the complementizer that such movement crosses".

Our proposal clearly aligns with the "extraction site" of accounts: in fact-as we have already emphasized - the low position from which the subject is extracted is the necessary condition for the that-t effect to be circumvented. However, this does not suffice; in fact, the presence of the expletive particle - $d a$ plays a fundamental role in characterizing the featural content of the COMP. In comparative terms, Cimbrian -da corresponds to the so-called "expletive pro" 4 in German, which is assumed in (i) impersonal passive constructions (see $19 a, b)$; (ii) unaccusative verbs $(20 a, b)$; and (iii) passive $(21 a, b)$ :

\begin{tabular}{|c|c|c|c|c|c|c|c|}
\hline 19. a. & $\begin{array}{l}\text { Gestern } \\
\text { yesterday }\end{array}$ & $\begin{array}{l}\text { wurde } \\
\text { was }\end{array}$ & pro & $\begin{array}{l}\text { die ganze Nacht } \\
\text { the whole night }\end{array}$ & \multicolumn{2}{|l|}{$\begin{array}{l}\text { getanzt } \\
\text { danced }\end{array}$} & (Ger.) \\
\hline b. & $\begin{array}{l}\text { Gestarn } \\
\text { yesterday } \\
\text { 'Yesterday }\end{array}$ & $\begin{array}{l}\text { iz-ta } \\
\text { is-da.CL } \\
\text { there was d }\end{array}$ & $\begin{array}{l}\text { khent } \\
\text { gone } \\
\text { ancing all }\end{array}$ & $\begin{array}{l}\text { getånzt } \\
\text { danced } \\
\text { iight long.' }\end{array}$ & \multicolumn{2}{|c|}{$\begin{array}{l}\text { da gånz nacht } \\
\text { the whole night }\end{array}$} & (Cimb.) \\
\hline 20. a. & $\begin{array}{l}\text { Gestern } \\
\text { yesterday }\end{array}$ & $\begin{array}{l}\text { sind } \\
\text { are }\end{array}$ & pro & $\begin{array}{l}\text { meine Freunde } \\
\text { my friends }\end{array}$ & \multicolumn{2}{|l|}{$\begin{array}{l}\text { gekommen } \\
\text { arrived }\end{array}$} & (Ger.) \\
\hline b. & $\begin{array}{l}\text { Gestarn } \\
\text { yesterday } \\
' \text { Yesterday }\end{array}$ & $\begin{array}{l}\text { soin-da } \\
\text { are-da.CL } \\
\text { my friends }\end{array}$ & $\begin{array}{l}\text { gerift } \\
\text { arrived } \\
\text { arrived.' }\end{array}$ & $\begin{array}{l}\text { moine tschelln } \\
\text { my friends }\end{array}$ & & & (Cimb.) \\
\hline 21. a. & $\begin{array}{l}\text { Gestern } \\
\text { yesterday }\end{array}$ & $\begin{array}{l}\text { wurde } \\
\text { was }\end{array}$ & pro & $\begin{array}{l}\text { vom Professor } \\
\text { by.the professor }\end{array}$ & $\begin{array}{l}\text { Hans } \\
\text { Hans }\end{array}$ & $\begin{array}{l}\text { gelobt } \\
\text { praised }\end{array}$ & (Ger.) \\
\hline b. & $\begin{array}{l}\text { Gestarn } \\
\text { yesterday }\end{array}$ & $\begin{array}{l}\text { iz-ta } \\
\text { is-da.CL }\end{array}$ & $\begin{array}{l}\text { khent } \\
\text { gone }\end{array}$ & $\begin{array}{l}\text { lodart } \\
\text { praised }\end{array}$ & $\begin{array}{l}\text { dar Håns } \\
\text { the Hans }\end{array}$ & $\begin{array}{l}\text { von professor } \\
\text { by.the professor }\end{array}$ & (Cimb.) \\
\hline
\end{tabular}

'Yesterday Hans was praised by the professor.'

Furthermore, the expletive - $d a$ provides morphological evidence to the hypothesis that a subject extraction from an embedded clause, introduced by a lexical complementizer, implies a copy in the vP-internal position. In other words, -da manifests the morphological exponent of the Agree relation between the probe $\mathrm{C}$ and the low DP subject (see Bidese and Tomaselli 2018; Bidese et al. 2020). We argue that $C$ probes the low subject, as $T$ is assumed to be deficient: in fact, it does not act as a probe, nor does it attract the finite verb; hence, it is not the locus of nominative case assignment. Consequently, [Spec, TP] is not projected in Cimbrian as the absence of a German-like verb-subject inversion confirms (cf. 3); for further details, we refer the reader to Bidese et al. (2020).

In Italian, $\mathrm{T}$ is endowed with tense features, which are rich enough to both incorporate the null subject pronoun and satisfy the EPP feature (see also Holmberg 2010, p. 99). Consequently, [Spec, TP] is not projected in Italian, as the rich verb morphology can be assumed to contain the features that characterize a pro (see Biberauer and Roberts 2010). In particular, Biberauer (2010, p. 164) proposes a refinement of this assumption, decomposing the tense feature in two sub-feature sets, both connected with verbal morphology, i.e., its nominal strand [D] (as in person and number) and its verbal strand [V] (as in tense, aspect, and mood). Thus, for different reasons, [Spec, TP] is inactive both in Italian and in Cimbrian and cannot function as an intermediate position for the extracted elements: in both languages, we expect a (definite) nominal subject to be extracted directly from either a vP internal or an extraposed position.

If [Spec, TP] is not involved in subject extraction or in NOM assignment, the lexical complementizer does not act as an intervener:

4 As a reviewer points out, this assumption is far from being uncontroversial. We refer the reader to classical references such as Sternefeld (1985) and Grewendorf (1989), in favor of our view, and Haider (1993), against it. 


$$
\begin{array}{lll}
\text { a. } & \text { Wh } \ldots\left[C P \ldots \left[\text { FinP } \left[\operatorname{Fin}^{0} a z+d a\right.\right.\right. & [\mathrm{TP}[\mathrm{vP} \ldots \mathrm{Wh}]]]] \\
\text { b. } & \mathrm{Wh} \ldots\left[\mathrm { CP } k e \ldots \left[\text { FinP XP } \left[\operatorname{Fin}^{0} V \text { fin }+d a\right.\right.\right. & [\mathrm{TP}[\mathrm{vP} \ldots \mathrm{Wh}]]]]]
\end{array}
$$

To sum up, Cimbrian - $d a$ provides morphological evidence for the inactivation of [Spec, TP]; whereas, in Standard Italian, this follows directly from the positive value of the null subject parameter ${ }^{5}$.

\section{How Bavarian Circumvents the That-T Effect: Morphological Agreement in C}

Among German dialects and Germanic languages in general, there is a great deal of variation with respect to that-t effects (see Featherston 2005; Bayer and Salzmann 2013; Weiß 2017; Schippers et al. 2020). In particular, Bavarian is known to have both strategies to extract the wh-subject from an embedded clause, i.e., by either having the C-head hosting the finite verb, as in German (see 23a, 24a), or violating the that-t filter, as in Italian (23b,

\begin{tabular}{|c|c|c|c|c|}
\hline 23. a. & $\begin{array}{l}\text { Wer moanst-n, } \\
\text { who think.2PS.PT }\end{array}$ & $\begin{array}{l}\text { hod } \\
\text { has }\end{array}$ & $\begin{array}{l}\text { des Buach } \\
\text { the book }\end{array}$ & $\begin{array}{l}\text { g'lesn? } \\
\text { read }\end{array}$ \\
\hline b. & $\begin{array}{l}\text { Wer moanst-n, } \\
\text { who think.2PS.PT } \\
\text { 'Who do you think }\end{array}$ & $\begin{array}{l}\text { dass } \\
\text { that } \\
\text { has rea }\end{array}$ & $\begin{array}{l}\text { des Buach } \\
\text { the book } \\
\text { the book?' }\end{array}$ & $\begin{array}{l}\text { g'lesn hod? } \\
\text { read has }\end{array}$ \\
\hline 24. a. & $\begin{array}{l}\text { Wer moansd-n, } \\
\text { who think.2PP.PT }\end{array}$ & & $\begin{array}{l}\text { kummt } \\
\text { goes }\end{array}$ & $\begin{array}{l}\text { (in d'Mess)? } \\
\text { (to Mass) }\end{array}$ \\
\hline b. & $\begin{array}{l}\text { Wer moanst-n, } \\
\text { who think.2PS.PT }\end{array}$ & $\begin{array}{l}\text { dass } \\
\text { that }\end{array}$ & $\begin{array}{l}\text { (in d'Mess) } \\
\text { (to Mass) }\end{array}$ & $\begin{array}{l}\text { kummt? } \\
\text { goes }\end{array}$ \\
\hline
\end{tabular}
24b):

As the examples above show, Bavarian appears to be a partial pro-drop language (see Weiß and Volodina 2018), as only the second person singular and the first and second person plural allow for covert subjects; however, it disallows subject extraposition to the right of the verbal complex:

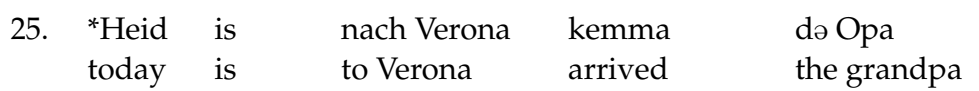

The only way to ameliorate (25) is to express a doubled subject via a pronominal enclitic subject to the right of the complementizer (COMP-cl): in this case, the DP subject can occur as right-dislocated, even though it is not necessary.

$\begin{array}{lllll}\text { 26. Heid } & \text { is-a } & \text { nach Verona } & \text { kemma } & \text { (də Opa) } \\ \text { today } & \text { is-he.CL } & \text { to Verona } & \text { come } & \text { (the grandpa) }\end{array}$

'Today, grandpa arrived in Verona.'

The import of the Bavarian data-with particular reference to the violation of the that-t effect-prompts us to further elaborate on some of the previous assumptions: First, we emphasize that the that-t violation seems not to be affected by the VO or OV word orders: On the one hand, the main difference concerns the position of the DP subject with respect to the past participle (which is extraposed in one case and vP-internal in the other); on the other hand, the common aspect is the countercyclic extraction of the wh-subject directly out of the low position, with an intermediate copy in [Spec, TP] that cannot be assigned a case by $\mathrm{C}$. This latter aspect brings the relation between $\mathrm{C}$ and $[\mathrm{Spec}, \mathrm{TP}]$ to the fore. In our view, it is the morphology in $C^{6}$ that is responsible for case absorption/case discharging. Notice, however, that this does not imply that the morphological agreement in $\mathrm{C}$ is morphologically overt. In fact, contrary to Cimbrian, Bavarian seems to rely on a strategy based on the D feature absorption, which is somehow reminiscent of the Italian strategy. In fact, we presume that Bavarian is essentially characterized by a full paradigm

5 Direct morphological evidence is attested in Italian dialects, cf. the Florentine examples in (35), taken from Brandi and Cordin (1989).

6 For the structural correlation between wh-extraction and complementizer agreement, see Weiß and Strobel (2018). 
of COMP agreement morphology, in which the first and third person singular agreement are in fact phonetically empty, and Cimbrian - $d a$ represents the overt counterpart of the third person (along the lines of Tomaselli and Bidese 2019).

It is reasonable to assume that, in both Cimbrian and Bavarian, an Agree relation does not take place between $C$ and $\mathrm{T}$ : in other words, the Cimbrian - $d a$ and Bavarian COMP agreement represent the morphological manifestation of $\mathrm{CP}$ keeping its features (in the sense of Ouali 2008) and not entering an Agree relation with [Spec, TP].

27.
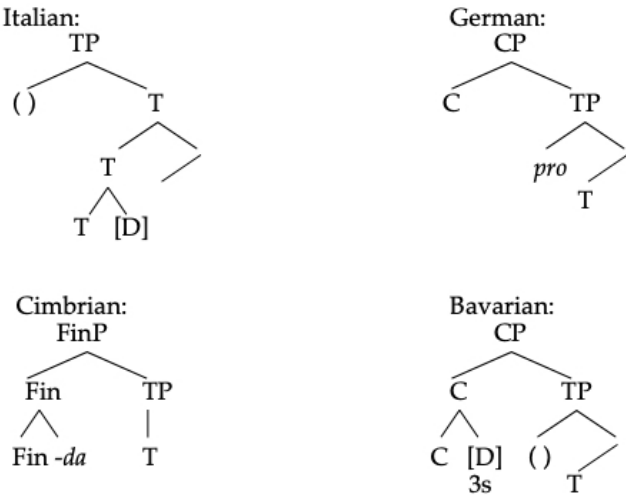

When the agreement between COMP and [Spec, TP] holds, i.e., through the presence of a third person subject pronoun encliticized onto the lexical complementizer, then subject extraction is ruled out in both Cimbrian (28) and Bavarian (29). In fact, the subject pronoun does not represent COMP agreement morphology:

28.
a. *Ber gloabest-(t)o,
$\mathrm{azz}=\mathbf{a r}$
habe
gelest
b. *Ber gloabest-(t)o,
azz=ar
khemm
ka miss?
who believe-you.CL
that-he.CL
come.SBJV to Mass

disan libar?

29. a. *Wer moanst-n, dass=a des Buach g'lesn hod?

b. *Wer moanst-n, dass=a (in d'Mess) kimmt/kummt?

As a matter of fact, COMP agreement hinges on the V-to-C movement in Germanic varieties. In the next section, we will deal with the que/qui alternation in French, which represents the Romance counterpart of COMP agreement activated by subject extraction, independent of the T-to- $\mathrm{C}$ movement.

\section{The quelqui Alternation in French: A Reappraisal}

That the French complementizer que alternates with qui in the contexts of subject extraction has been a well-known grammatical feature in Romance linguistics since Kayne (1975) and Rizzi (1982) and has been recently revived in Mackenzie (2018):

30. Et qui croyez-vous qui paye le déficit?
and who think-you qui is paying the deficit
'Who do you think is paying the deficit?'

Substituting que for qui in (30) would make the sentence ungrammatical. This occurrence of qui is often referred to as "special qui" to distinguish it from the wh-pronoun qui. In fact, classic analyses assume that qui is the nominative counterpart of the interrogative/relative pronoun qui that occurs after prepositions:

31. Àqui veux-tu que je le dise?

to whom want-you that I it tell

'Who do you want me to tell?' (Mackenzie 2018, p. 33)

On the contrary, there is strong evidence that the special qui behaves syntactically similar to que, i.e., like a $\mathrm{C}^{0}$. Mackenzie follows the lead of Koopman and Sportiche (2014) 
in assuming that subject extraction from sentences introduced by qui is necessary, since case assignment cannot occur clause-internally, and the extracted subject has its case feature checked by an external probe. However, Mackenzie refutes Koopman and Sportiche's assumption that qui is a relative pronoun. Mackenzie takes qui to be unequivocally a complementizer, albeit with a more complex morphological structure than que. In fact, there is diachronic evidence that qui can be decomposed to $q u(e)+i$, where $-i$ is taken to be a reduced form of the pronoun il. Il was originally inserted along with the complementizer as a resumptive pronoun; eventually, it underwent a process of grammaticalization and lost its person- and number-features, thus becoming a morphologically bound morpheme (see Mackenzie 2018, p. 32).

A strong assumption holds that qui-clauses (see 32c) are reminiscent of infinitival complements with subject extraction and ECM-like case assignment, as seen in $(32 \mathrm{a}, \mathrm{b})$ :

32. a. *On croit cet homme être malade

b. L'homme qu'on crois [ $t$ être malade]

c. Un homme que je crois [qu+i $t$ est malade]

The subject cannot be case-marked in (32a). However, when the subject is whextracted, ungrammaticality dissolves (cf. 32b, c).

In (33), we reproduced the syntactic representation of Mackenzie's analysis: abstracting away from the cartographic details of it, the most relevant aspect is that the wh-subject cannot be case-marked (either in $\mathrm{vP}$ or in [Spec, TP]) and has to enter a probe-goal relation, with a higher probe in the superordinate clause.

33.

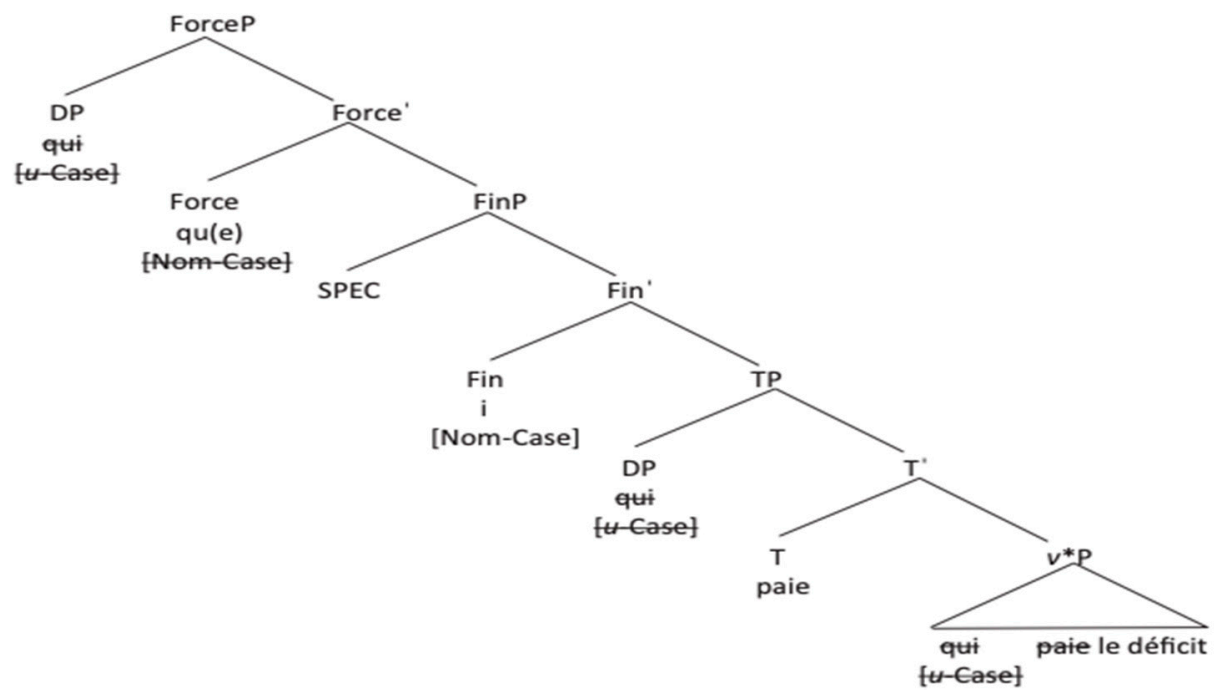

According to Mackenzie's proposal, the French data confirm what we have hitherto assumed:

(i) Irrespective of [Spec, TP] being the locus of cyclic wh-extraction, that position does not enter a probe-goal relation with the phase head.

(ii) The nominative case is 'absorbed'-i.e., in Mackenzie's terminology, "discharged" by $-i$, which overtly manifests Agree.

In (34), we introduce the French way of circumventing the that-t effect, compared with the ones we discussed in Sections 3 and 4: Cimbrian, Bavarian, and French, all converge in inhibiting the Agree relation between the phasal head C/Fin and [Spec, TP]. The strategy that all the three languages share is represented by a morphologically complex $C$-head with the following property: The Cimbrian $-d a$, the Bavarian C-Agr, and the French $-i$ absorb the case feature, i.e., the yield/product of the Agree relation, before it can be transferred to $\mathrm{T}$, preventing [Spec, TP] from entering the Agree relation with $\mathrm{C}$ as a suitable goal. 
34.

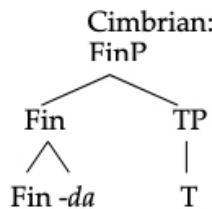

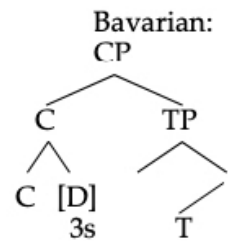

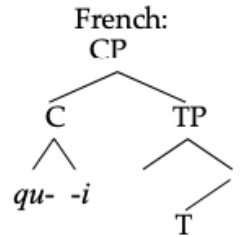

Regardless of the peculiar differences in every language, Mackenzie's assumption further confirms the idea that subject extraction through a lexical COMP is only possible when case is not licensed in the $\mathrm{T}$ layer.

Our proposal finds further confirmation in the Italo-Romance data presented in Brandi and Cordin (1989):

$\begin{array}{lllllll}\text { 35. Quante ragazze } & \text { tu } & \text { credi } t & \text { che } & \mathrm{e}^{\prime} & \text { sia } & \text { venuto } t \text { ? } \\ \text { how.many girls } & \text { you } & \text { believe } & \text { that } & \text { EXPL } & \text { is.SBJV } & \text { come.MASC.SING }\end{array}$

In Florentine, wh-extraction is only possible with an expletive proclitic subject (see $e^{\prime}$ in 35), which shows that there cannot be agreement between $\mathrm{T}$ and the internal argument, along with the absence of past participle agreement; In other words, wh-subject extraction is necessary, since the subject cannot be case-marked in the embedded clause, in the same fashion as in French (see 32c). Whenever an Agree relation is established between $\mathrm{T}$ and the internal argument via a clitic endowed with phi-features (see $l e$ in 35), along with the agreement of the past participle, the extraction is blocked, and the sentence is ungrammatical:

$\begin{array}{llllllll}\text { 35. Quante ragazze } & \text { tu } & \text { credi } t & \text { che } & \text { le } & \text { siano } & \text { venute } & t \\ \text { how.many girls } & \text { you } & \text { believe } & \text { that } & \text { EXPL } & \text { are.SBJV } & \text { come.FEM.PL } & \end{array}$

It goes without saying that subject proclitics realize agreement (third person plural) in the T domain (see Tomaselli and Bidese 2019).

\section{Conclusions}

In this paper, we have dealt with the phenomenon of that-t effect in a comparative perspective, focusing on the Germanic/Romance divide. All the languages considered here display a long wh-subject extraction across an overt COMP. In other words, they all violate/circumvent the that-t effect. Despite this superficial similarity in terms of E-language, all these languages make use of different strategies that boil down to the same mechanism in terms of I-Language: the inhibition of the Agree relation between a probe, endowed with phi-features, and [Spec, TP] as goal. In Cimbrian, this relation is inhibited because [Spec, TP] is assumed not to be projected (see Bidese and Tomaselli 2018; Bidese et al. 2020), and the particle - $d a$ manifests the relation between C-the phasal head endowed with phi-features-and the low subject position without involving T. Contrarily, in a pro-drop language such as Italian, it is $\mathrm{T}$ which plays a major role: the incorporation of the [D] features into the $T$ head ensures that the Case feature of $T$ is discharged in the richly articulated morphological layer of the probe itself. In turn, [Spec, TP] does not play any role in case assignment. The same incorporation of the [D] features occurs in C, in a V2 language like Bavarian: in this variety, the case feature of $C$ is absorbed/discharged directly on the C-head due to the phenomenon of COMP-agreement (even when the Agr exponent is $\varnothing$ ). In a similar way, the morphological exponent $-i-i n$ the French complex head $q u-i-$ absorbs the case feature in $\mathrm{C}$, resulting in the inactivation of [Spec, TP].

The general conclusion we can draw is that each of the four languages described manifests a specific facet of the same operation: [Spec, TP] ends up not being involved in the Agree relation with the probing head.

In a null subject language, the that-t effects can be circumvented by incorporating [D] in T; on the contrary, in non-pro-drop languages, [D] is incorporated in C, with the result of rendering $[\mathrm{Spec}, \mathrm{TP}]$ inactive. 
Author Contributions: The overall paper is the result of joint work but each author provided their own individual contribution: conceptualization A.T. and E.B.; methodology, A.T., A.P. and E.B.; formal analysis A.T., A.P. and E.B.; investigation and data curation E.B.; writing E.B. and A.P.; supervision A.T. For the concerns of the Italian Academia, A.P. takes responsibility of Sections 3 and 4; E.B. of Sections 1 and 2. A.T. for Sections 5 and 6. All authors have read and agreed to the published version of the manuscript.

Funding: This research was funded by the PRIN project "Models of language variation and change: new evidence from language contact" of the Italian Ministry of Education, University and Research, grant nr. 2017K3NHHY (PI: Maria Rita Manzini).

Institutional Review Board Statement: Not applicable.

Informed Consent Statement: Informed consent was obtained from all subjects involved in the study.

Data Availability Statement: The most part of the data discussed are taken from previous literature; novel data concerning the that-t effect have been collected both with dedicated fieldwork and from the crowdsourcing platform, www.vinko.it (accessed on 15 March 2021) (data available in a publicly accessible repository)

Acknowledgments: We would like to express our deep gratitude to three anonymous reviewers of Languages who helped us improve the contribution by strengthening the arguments and working out some entangled parts.

Conflicts of Interest: The authors declare no conflict of interest.

\section{References}

Bayer, Josef, and Martin Salzmann. 2013. That-trace effects and resumption-How improper movement can be repaired. In Repairs-The Added Value of Being Wrong. Edited by Patrick Brandt and Erik Fuß. Berlin: de Gruyter, pp. 275-333.

Belletti, A. 2004. Aspects of the Low IP Area. In The Structure of CP and IP. The Cartography of Syntactic Structures, Vol. 2. Edited by Luigi Rizzi. New York: Oxford University Press, pp. 16-51.

Biberauer, Theresa. 2010. Semi Null-Subject languages, expletives and expletive pro reconsidered. In Parametric Variation: Null Subjects in Minimalist Theory. Edited by Theresa Biberauer, Anders Holmberg, Ian Roberts and Michelle Sheehan. Cambridge: Cambridge University Press, pp. 153-99.

Biberauer, Theresa, and Ian Roberts. 2010. Subjects, Tense and verb-movement. In Parametric Variation: Null Subjects in Minimalist Theory. Edited by Theresa Biberauer, Anders Holmberg, Ian Roberts and Michelle Sheehan. Cambridge: Cambridge University Press, pp. 263-302.

Bidese, Ermenegildo. 2004. Die Zimbern und ihre Sprache: Geographische, historische und sprachwissenschaftlich relevante Aspekte. In Alte Sprachen: Beiträge zum Bremer Kolloquium über 'Alte Sprachen und Sprachstufen'. Edited by Thomas Stolz. Bochum: Bockmeyer, pp. 3-42.

Bidese, Ermenegildo. 2008. Die diachronische Syntax des Zimbrischen. Tübingen: Gunter Narr.

Bidese, Ermenegildo. 2010. Il Cimbro Negli Studi di Linguistica. Edited by Ermenegildo Bidese. Padua: Unipress.

Bidese, Ermenegildo. 2017. Reassessing contact linguistics. Signposts towards an explanatory approach to language contact. Zeitschrift für Dialektologie und Linguistik LXXXIV: 126-51.

Bidese, Ermenegildo, and Alessandra Tomaselli. 2016. The decline of asymmetric word order in Cimbrian subordination and the special case of umbrómm. In Co- and Subordination in German and Other Languages. Edited by Ingo Reich and Augustin Speyer. Hamburg: Buske Verlag, pp. 55-75.

Bidese, Ermenegildo, and Alessandra Tomaselli. 2018. Developing pro-drop: The case of Cimbrian. In Null Subjects in Generative Grammar: A Synchronic and Diachronic Perspective. Edited by Federica Cognola and Jan Casalicchio. Oxford: Oxford University Press, pp. 52-69.

Bidese, Ermenegildo, Andrea Padovan, and Alessandra Tomaselli. 2012a. A binary system of complementizers in Cimbrian relative clauses. Working Papers in Scandinavian Syntax 90: 1-21.

Bidese, Ermenegildo, Federica Cognola, and Andrea Padovan. 2012b. Zu einer neuen Verb-Zweit-Typologie in den germanischen Sprachen: Der Fall des Zimbrischen und des Fersentalerischen. In In Simplicitate Complexitas. Festgabe für Barbara Stefan zum 70. Geburtstag. Edited by Peter Anreiter, Ivo Hajnal and Manfred Kienpointner. Wien: Praesens Verlag, pp. 69-86.

Bidese, Ermenegildo, Andrea Padovan, and Alessandra Tomaselli. 2013. Bilingual competence, complementizer selection and mood in Cimbrian. In Dialektologie in neuem Gewand. Zu Mikro-/Varietätenlinguistik, Sprachenvergleich und Universalgrammatik. Edited by Werner Abraham and Elisabeth Leiss. Hamburg: Helmut Buske Verlag, pp. 47-58.

Bidese, Ermenegildo, Andrea Padovan, and Alessandra Tomaselli. 2020. Rethinking Verb Second and Nominative case assignment: New insights from a Germanic variety in Northern Italy. In Rethinking Verb Second. Edited by Rebecca Woods and Sam Wolfe. Oxford: Oxford University Press, pp. 575-93. 
Brandi, Luciana, and Patrizia Cordin. 1989. Two Italian Dialects and the Null Subject Parameter. In The Null Subject Parameter. Edited by Osvaldo A. Jaeggli and Kenneth J. Safir. Dordrecht: Springer, pp. 111-42.

den Besten, Hans. 1983. On the interaction of root transformations and lexical deletive rules. In On the Formal Syntax of the Westgermania. Edited by Werner Abraham. Amsterdam: Benjamins, pp. 47-131.

Featherston, Sam. 2005. that-trace in German. Lingua 115: 1277-302. [CrossRef]

Grewendorf, Günther. 1989. Ergativity in German. Dordrecht: Foris.

Grewendorf, Günther, and Cecilia Poletto. 2009. The hybrid complementizer system of Cimbrian. In Proceedings XXXV Incontro di Grammatica Generativa. Edited by Vincenzo Moscati and Emilio Servidio. Siena: Centro Interdipartimentale di Studi Cognitivi sul Linguaggio, pp. 181-94.

Haider, Hubert. 1993. Deutsche Syntax - Generativ. Vorstudien zur Theorie Einer Projektiven Grammatik. Tübingen: Gunter Narr.

Holmberg, Anders. 2010. Null Subject Parameter. In Parametric Variation: Null Subjects in Minimalist Theory. Edited by Theresa Biberauer, Anders Holmberg, Ian Roberts and Michelle Sheehan. Cambridge: Cambridge University Press, pp. 88-124.

Kayne, Richard S. 1975. French Syntax: The Transformational Cycle. Cambridge: Massachusetts Institute of Technology Press.

Kolmer, Agnes. 2005. L'elemento da come espletivo della posizione del soggetto enclitico pronominale nel Cimbro di Luserna (Trentino). In L'influsso dell'italiano sulla grammatica delle lingue minoritarie. Problemi di morfologia e sintassi. Atti del Convegno Internazionale-Costanza, 8.-11.10.2003. Edited by Walter Breu. Rende: Università della Calabria, pp. 55-78.

Koopman, Hilda, and Dominique Sportiche. 2014. The que/qui alternation: New analytical directions. In Functional Structure from Top to Toe: The Cartography of Syntactic Structures. Edited by Peter Arne Svenonius. Oxford: Oxford University Press, pp. 46-96.

Mackenzie, Ian. 2018. The Case of special qui. Journal of French Language Studies 28: 21-41. [CrossRef]

Ouali, Hamid. 2008. On C-to-T $\varphi$-Feature Transfer: The nature of Agreement and Anti-Agreement in Berber. In Agreement Restrictions. Edited by Roberta D'Alessandro, Gunnar Hrafn Hrafnbjargarson and Susann Fischer. Berlin: Mouton de Gruyter, pp. 159-80.

Padovan, Andrea. 2011. Diachronic Clues to Grammaticalization Phenomena in the Cimbrian CP. In Studies on German language-islands. Edited by Michael T. Putnam. Amsterdam/Philadelphia: John Benjamins Publishing Company, pp. 279-300.

Panieri, Luca, Monica Pedrazza, Adelia Nicolussi Baiz, Sabine Hipp, and Cristina Pruner. 2006. Bar lirnen z'schraiba un zo reda az be biar. Grammatica del cimbro di Luserna / Grammatik der zimbrischen Sprache von Lúsern. Trento: Regione Autonoma Trentino-Alto Adige/Autonome Region Trentino-Südtirol \& Istituto Cimbro/Kulturinstitut Lúsern.

Pesetsky, David. 2017. Complementizer-Trace Effects. In The Wiley Blackwell Companion to Syntax, 2nd ed. Edited by Martin B. H. Everaert and Henk van Riemsdijk. Hoboken: Wiley-Blackwell, pp. 1-34.

Rizzi, Luigi. 1982. Issues in Italian Syntax. Dordrecht: Foris.

Rizzi, Luigi. 2004. Locality and Left Periphery. In Structures and Beyond. The Cartography of Syntactic Structures. Edited by Adriana Belletti. Oxford: Oxford University Press.

Schippers, Ankelien, Margreet Vogelzangand, and David Öwerdieck. 2020. Nordlyd 44.1: 117-32 [=CGSW 34: Proceedings of the 34th Comparative Germanic Syntax Workshop held in Konstanz in 2019. Edited by Andreas Trotzke and George Walkden. Tromsø: The Arctic University of Norway. [CrossRef]

Sternefeld, Wolfgang. 1985. On case and binding theory. In Studies in German Grammar. Edited by Jindřich Toman. Dordrecht: Foris, pp. 231-87.

Tomaselli, Alessandra, and Ermenegildo Bidese. 2019. Subject clitic languages in comparison. Subject clitics, finite verb movement, and nominative case assignment in Germanic (Bavarian, Cimbrian) and Romance (French, North Italian) varieties. In La linguistica vista dalle Alpi. Teoria, lessicografia e multilinguismo-Linguistic views from the Alps. Language Theory, Lexicography and Multilingualism. Edited by Ermenegildo Bidese, Jan Casalicchio and Manuela Caterina Moroni. Berlin: Peter Lang, pp. 43-61.

Weiß, Helmut. 2017. Dialektsyntax-Status und Relevanz eines modernen Forschungsfeldes. In Dynamik, Struktur und Funktion bayerisch-österreichischer Varietäten. Edited by Alexandra N. Lenz, Ludwig M. Breuer, Peter Ernst, Manfred Glauninger, Tim Kallenborn and Franz Patocka. Stuttgart: Steiner, pp. 13-32.

Weiß, Helmut, and Thomas Strobel. 2018. Neuere Entwicklungen der Dialektsyntax. Linguistische Berichte 253: 3-35.

Weiß, Helmut, and Anna Volodina. 2018. Referential Null Subjects in German: Dialects and Diachronic Continuity. In Null Subjects in Generative Grammar. A synchronic and Diachronic Perspective. Edited by Federica Cognola and Jan Casalicchio. Oxford: Oxford University Press, pp. 261-84.

Wiklund, Anna-Lena, Kristine Bentzen, Gunnar Hrafn Hrafnbjargarson, and Porbjörg Hróarsdóttir. 2009. On the distribution and illocution of V2 in Scandinavian that-clauses. Lingua 119: 1914-38. [CrossRef] 